\title{
Meta
}

Journal des traducteurs

Translators' Journal

\section{Kellman, S.G. (ed.) (2003): Switching Languages: Translingual Writers Reflect on Their Craft, Lincoln/London, University of Nebraska Press, XIX + 339 p.}

\section{Kathleen Connors}

Volume 49, numéro 4, décembre 2004

URI : https://id.erudit.org/iderudit/009793ar

DOI : https://doi.org/10.7202/009793ar

Aller au sommaire du numéro

Éditeur(s)

Les Presses de l'Université de Montréal

ISSN

0026-0452 (imprimé)

1492-1421 (numérique)

Découvrir la revue

Citer ce compte rendu

Connors, K. (2004). Compte rendu de [Kellman, S.G. (ed.) (2003): Switching

Languages: Translingual Writers Reflect on Their Craft, Lincoln/London,

University of Nebraska Press, XIX + 339 p.] Meta, 49(4), 934-935.

https://doi.org/10.7202/009793ar d'utilisation que vous pouvez consulter en ligne.

https://apropos.erudit.org/fr/usagers/politique-dutilisation/ 
in academic basis. CTT tries to sort out the propositions of traditional Chinese translation theories and transform them into modern ones. Traditional Chinese translation theories are weak in theoretical consciousness, but contain some valuable propositions such as literal and liberal translations, literal translation and retranslation, transliteration and liberal translation, translating meaning and taste, alike in spirit and form, criteria, translatability, lofty realm, language, and translator. The book, in the light of the planning of modern translation theory, transforms them into ontology, methodology, epistemology, criterion or principle, subjectivity, and translatability. It considers that they lack the propositions such as translation process, effect evaluation, style correspondence, semantic transference, and translation criticism.

CTT is completed through the process of sorting out, interpretation, transference, ending and sublimation of traditional Chinese translation theories. This approach is of great value in theory and methodology, and it is of great significance in translation studies. It opens a new era in studying the traditional Chinese translation theories.

Apart from the above sections, the appendix of the book, by summing up its author's experiences, proposes ten expressionistic approaches for literary translation. They include naming and renaming, sentence rendering, concision and consideration, unity and variety, taste and plasticity, image and imagination, rhythm in freedom, cohesion in fluency, textuality redesigned, and title and type. It also proposes the criteria for literary translation: literary format, poetic taste, language expression, cultural consideration, ideological inclination, and style typology. Based on the criteria, it divides translation products into three levels: excellent, good and clumsy. These achievements will undoubtedly promote the development of literary translation studies.

In sum, the book under review is extremely useful, although it only chooses ten typical traditional Chinese translation theories, and these are sometimes inharmonious in style.

XU JiANZHONG

Shaanxi University of Science and Technology, Xianyang, Shaanxi, China

Kellman, S.G. (ed.) (2003): Switching Languages: Translingual Writers Reflect on Their Craft, Lincoln/London, University of Nebraska Press, xıx +339 p.

This book is a collection of articles and excerpts from the works of authors who write or have written in a second language or, in rare cases, have refused to do so. More often than not, the second language in question is English. The pieces range from a nine-line poem to a 21-page book excerpt. A few of them are (English) translations, in three cases by the editor himself.

In a number of these texts, the authors are explaining either why they write in their second language or what it feels like to do so. The original English pieces here (the majority) show that their authors are remarkable writers of this second language. The other general observation one can easily make is that, at the moment, English is the language which writers wishing to reach a world audience learn to write in.

An important exception to this latter generalization is, of course, French. The editor has translated into English a sample of the French writings of Léopold Sédar Senghor (pp. 3541) and of Assia Djebar (pp. 311-318). Not surprisingly, the other language from which the editor has translated a sample of a bilingual writer's work is Spanish. This is the case of Esmeralda Santiago's "Introduction to Cuando era puertorriqueña" (pp. 131-134).

Translation is also represented directly by "The Prague Manifesto," issued on the occasion of the Eighty-First World Esperanto Congress in July 1996, and printed here in the 
original Esperanto (pp. 25-27). Its unsigned English translation, also from Prague on the same date, figures on pages 29-31. In addition, Ngùgì Wa Thiong'o's "Imperialism of Language," drawn from his English, a Language for the World? appears in a translation from the Gikùyù, by the author and Wangùi wa Goro, on pages 169-181.

As well, the excerpt from Elias Canetti's The Play of the Eyes (pp. 301-307) was translated from the German by Ralph Manheim for the publication of Canetti's memoirs in English in 1999. Marjorie Agosín's contribution, from “Words: A Basket of Love” (pp. 321326), a chapter of this author's The Alphabet in My Hands: A Writing Life, was translated from the Spanish by Nancy Abraham Hall. Hana Wirth-Nesher translated Baal-Makhshoves' "One Literature in Two Languages" (pp. 99-109) from the Yiddish, the other language alluded to being Hebrew. Finally, the editor himself interviewed Ha Jin (pp. 81-84) and Chang-rae Lee (pp. 91-94), in English, and it is the transcript of each of these interviews which appears here. In the case of all the 19 other texts, their originally non-Anglophone authors wrote them themselves, in English.

Writers as well known as Salman Rushdie ("Damme, This Is the Oriental Scene for You!," pp. 245-260), Arthur Koestler (an excerpt from “Becoming Anglicized,” pp. 291-292), Chinua Achebe ("The African Writer and the English Language," pp. 191-200), Ian Buruma (“The Road to Babel," pp. 9-22), and Ilan Stavans (“Autobiographical Essay," pp. 113-127) are represented here. The longest and most engaging piece, however, is Luc Sante's "Dummy" (pp. 141-161), whose author is an American of Francophone Belgian origin, well known especially for his articles in The New York Review of Books.

Sante's text starts with an amusing account of how English, French, and Walloon feel in his head, and the visual, auditory, and olfactory images he associates with each of these languages. It continues, though, with a detailed account of the external history and macrosociolinguistics of the relation between Walloon and French. We learn, for example (pp. 153-154), that the "golden age" of Walloon literature was brief, starting about 1880, peaking exactly a century ago, and ending even before World War I. According to the author, it is not only 20th-century life that killed Walloon, but the French attitude toward language, which stigmatizes social and regional variation. He claims that the general Belgian reaction to this attitude has been uncritical acceptance (pp. 149-150), which has led not only to the loss of the indigenous Romance language of the peasant and working classes (Walloon), but also, and more humiliatingly, to that of "Belgicisms" within French. He even blames the Academy's attempts to suppress linguistic changes for the loss of the latter language's international political power to English (p. 150), an opinion sometimes voiced by Francophone linguists as well.

In concluding, Sante returns to the "spaces" occupied by his languages in his mental universe, epitomizing the sentiments of several multilingual authors represented here (p. 161):

I don't have a house, only this succession of rented rooms. That sometimes makes me feel as though I have no language at all, but it also gives me the advantage of mobility. I can leave, anytime, and not be found.

Kathleen Connors University of Montreal, Montreal, Canada

\section{Riccardi, A. (2003): Dalla traduzione all'interpretazione, Studi d'interpretazione} simultanea, Milan, Edizioni Universitarie di Lettere Economia Diritto, 302 p.

Alessandra Riccardi, professeur associé d'interprétation simultanée à la Scuola Superiore di Lingue Moderne per Interpreti e Traduttori de l'Université de Trieste, est interprète de conférence et rassemble dans ce livre plusieurs études sur l'interprétation, et plus particulièrement la 